The University of Maine

\title{
DigitalCommons@UMaine
}

Anthropology Faculty Scholarship

Anthropology

Winter 1-3-2015

\section{Mobility in the Mangroves: Catch Rates, Daily Decisions, and Dynamics of Artisanal Fishing in a Coastal Commons}

Christine M. Beitl

University of Maine - Main, christine.beitl@maine.edu

Follow this and additional works at: https://digitalcommons.library.umaine.edu/ant_facpub

Part of the Environmental Studies Commons, Human Ecology Commons, Latin American Studies Commons, Nature and Society Relations Commons, and the Social and Cultural Anthropology Commons

\section{Repository Citation}

Beitl, C. M. "Mobility in the Mangroves: Catch Rates, Daily Decisions, and Dynamics of Artisanal Fishing in a Coastal Commons" Applied Geography (2014), http://dx.doi.org/10.1016/j.apgeog.2014.12.008

This Article is brought to you for free and open access by DigitalCommons@UMaine. It has been accepted for inclusion in Anthropology Faculty Scholarship by an authorized administrator of DigitalCommons@UMaine. For more information, please contact um.library.technical.services@maine.edu. 


\section{THIS IS A PRE-PUBLICATION VERSION OF:}

Beitl, C. M. (2015) Mobility in the Mangroves: Catch Rates, Daily Decisions, and Dynamics of Artisanal Fishing in a Coastal Commons Applied Geography 59: 98-106 http://dx.doi.org/10.1016/j.apgeog.2014.12.008

(C) 2015. This manuscript version is made available under the CC-BY-NC-ND 4.0 license http://creativecommons.org/licenses/by-nc-nd/4.0

THE FINAL VERSION CAN BE FOUND AT THE FOLLOWING URL:

http://www.sciencedirect.com/science/article/pii/S0143622814002926

Mobility in the Mangroves: Catch Rates, Daily Decisions, and Dynamics of Artisanal Fishing in a Coastal Commons

Christine M. Beitl

Department of Anthropology

University of Maine

christine.beitl@maine.edu 


\title{
Mobility in the Mangroves: Catch Rates, Daily Decisions, and Dynamics of
}

\author{
Artisanal Fishing in a Coastal Commons
}

\begin{abstract}
This paper integrates institutional theories of the commons with insights from geography and human behavioral ecology to explore the spatial and temporal dynamics of artisanal fishing in Ecuador's coastal mangrove swamps. The focus is on the cockle fishery commons characterized by a mixture of formal institutional arrangements and an informal division of fishing space that partially influences fisher decisions about where and when to fish. Individual decisions are further explained to a certain degree by the patch choice model since fishers often move on to new grounds when their catch rates fall below average. These optimizing strategies requiring rotation within a socially produced fishing space may contribute to resource renewal, perceived reliable returns for individuals, and a relative stability in fishing effort, potentially mitigating against resource depletion in open-access areas not managed as a common property regime. This study of the interaction between shellfish harvesters, cultural institutions, and the environment contributes to a spatially explicit theory of the commons and points to the crucial role of resource user mobility and cultural institutions for the ecological sustainability of shellfish fisheries. A better understanding of feedback between individual decision-making and the self-organization of a social-ecological system has critical implications for policy design and fisheries management at similar scales.
\end{abstract}

Keywords: artisanal fisheries; decision making; common pool resource theory; optimal foraging theory; fisheries management; Ecuador

\section{Resumen}

En este trabajo se integra las teorías institucionales de los bienes comunes con los puntos de vista de la geografía y la ecología humana para explorar la dinámica espacial y temporal de la pesca artesanal en los manglares de Ecuador. La atención se centra en la pesquería de concha prieta caracterizada por arreglos institucionales formales y una división informal de espacio de pesca que influye parcialmente las decisiones de los mariscadores acerca de dónde y cuándo pescar. Las decisiones individuales se explican más detalladamente en cierta medida por el modelo de elección parche ya que los pescadores suelen trasladarse a nuevos terrenos cuando sus tasas de captura están por debajo de la media. Las estrategias de optimizar requiriendo rotación dentro de un espacio social pueden permitir la renovación del recurso, capturas fiables para los pescadores, y una estabilidad relativa en el esfuerzo pesquero, lo que podría mitigar contra el agotamiento de los recursos en las zonas de libre acceso no gestionados como un régimen de propiedad común. Este estudio de la interacción entre los mariscadores y su medio ambiente contribuye a una teoría de los bienes comunes espacialmente explícito y señala el papel crucial de la movilidad de los usuarios y las instituciones culturales para la sostenibilidad ecológica en la pesquería. Un mejor entendimiento sobre la interacción entre las decisiones y la auto-organización de un sistema socio-ecológico tiene 
implicaciones importantes para el diseño de políticas y la gestión de pesquerías en escalas similares.

Palabras claves: pesquerías artesanales; toma de decisiones; teoría de los bienes comunes; manejo de recursos; Ecuador

\section{Highlights:}

- A spatially explicit theory of the commons considers resource user mobility.

- Spatial and temporal dynamics of fishing effort emerge from individual decisions.

- Cultural institutions and previous-day catch rates influence fishers' decisions.

- Fishers alternate between formal and informal systems of governance.

- Formal and informal governance systems are complementary and adaptive.

\section{Acknowledgements}

This research was carried out with support from the National Science Foundation Doctoral Dissertation Improvement Grant (BCS-0819376), the Wenner Gren Foundation Dissertation Field Grant (Gr.8003), and the Institute for International Education Fulbright Fellowship. This paper is the result of collaboration with the Asociación de Mariscadores, Pescadores Artesanales y Afines "Costa Rica" in El Oro, Ecuador, and would not have been possible without their systematic CPUE data collection coordinated by Adolfo Cruz and Sonia Cruz. I am grateful to Arielle Levine for inviting me to contribute to this special issue. I also appreciate the critical comments and suggestions from Joshua Stoll and three anonymous reviewers. All errors and shortcomings are my own. 


\section{Mobility in the Mangroves: Catch Rates, Daily Decisions, and Dynamics of Artisanal Fishing in a Coastal Commons}

\section{Introduction}

As a classic example of common pool resources, fisheries face many management challenges due to the difficulty of excluding individuals whose harvesting efforts are costly for a larger population of resource users who compete for the same resource space (Berkes, 2001; Berkes, 2005; Feeny, Berkes, McCay, \& Acheson, 1990; Gordon, 1954). For geographers, the tragedy of the commons emerges out of mismatched scales in the interaction between the spatial domains of resources and resource users, in which selfinterested actions result in resource depletion (Campbell, 2007; Giordano, 2003). Overcoming a mismatch between management and ecosystem scales requires a better understanding of the spatial organization and complex interactions between human and natural systems at finer scales (Johnson, Wilson, Cleaver, \& Vadas, 2012; Wilson, 2006).

Over the last several decades, commons theory has advanced understanding about the importance of property rights institutions, which are often held as an essential mechanism for maintaining or improving resource systems (Agrawal, 2001; Basurto, 2005; Basurto et al., 2012; Bromley \& Feeny, 1992; Hanna, Folke, \& Mäler, 1996; Hanna \& Munasinghe, 1995; McCay \& Acheson, 1987; Schlager \& Ostrom, 1999). Similarly, customary marine tenure institutions have also been exalted in the literature as social systems that effectively manage resources through controlled access and regulated use (Colding \& Folke, 2001; Dyer \& McGoodwin, 1994; Johannes, 1978, 2002) notwithstanding some skepticism about the assumed conservation ethics embedded within those institutions (Lu, 2001; Pollnac \& Johnson, 2005; Ruttan, 1998; Thomas, 2001). Despite numerous theoretical advances about the crucial role of formal and informal institutions in environmental governance, the commons literature has given less explicit attention to how spatial-temporal dynamics of the commons are produced socially, politically and materially by various forms of human agency (Moss, 2014) and how system-level patterns can emerge out of the self-interested behaviors of individuals as a "precursor of governance" (Wilson, Yan, \& Wilson, 2007). These questions are especially critical considering that research on the spatial dimensions of fishing behavior is of burgeoning interest in the fisheries science and management literature (Abernethy, Allison, Molloy, \& Côté, 2007; Daw, 2008; Salas \& Gaertner, 2004; Teh, Teh, \& Meitner, 2012).

This paper explores dynamic spatial and temporal patterns in the fishing effort on a micro-scale, focusing on fisher decisions and the role of resource user mobility over fishing space in Ecuador's fishery for mangrove cockles (Anadara tuberculosa and A. similis). Mangrove cockles are bivalve mollusks harvested from the roots of mangrove trees during low tide periods by artisanal fishers throughout their range from Mexico to Peru (MacKenzie, 2001). I integrate institutional common pool resource theory (CPR) with optimal foraging theory (OFT) for its explicit attention to the human-environment interface to explore how fishers navigate over patchy ecological conditions and under different governance systems. OFT has traditionally been used in anthropology to study how foragers make decisions about resources to best enhance their fitness in a Darwinian sense (Kelly, 1995). However, some OFT models offer appropriate methodological tools to explore how resource users respond to ecological dynamics (Chimello de Oliveira \& 
Begossi, 2011; Sosis, 2002). As such, theories in human behavioral ecology have been increasingly applied to address practical issues in conservation, development, and resource management (Aswani, 1998; Aswani, 1998; Chimello de Oliveira \& Begossi, 2011; Heinen, 1995, 1996; Heinen \& Low, 1992; Tucker, 2007; Tucker \& Rende Taylor, 2007) and are compatible with rational choice theories and classical economic assumptions about human behavior in the fisheries literature (Acheson, 2011; Béné \& Tewfik, 2001; Hilborn, 2007).

Using catch-per-unit-effort (CPUE) data collected over four months in Isla Costa Rica, Ecuador, the scope of this paper is confined to three specific questions. First, how do catch rates of a previous day influence a fisher's decision about where to fish and when to move on? Second, how does the cultural and institutional context shape broader spatial patterns of mobility over fishing space? Finally, what are the management implications of this fine-scale analysis of the spatial-temporal dimensions of fishing effort? The activity of harvesting shells represents the human-environment interface where artisanal fishers interact with their biophysical environment and their culturalinstitutional context.

This case study of cockle fishing in Isla Costa Rica offers a unique opportunity to observe how changing social constructions of the commons influence dynamics of artisanal fishing and how fishers' alternate between two kinds of governance systems: 1) open-access fishing grounds with an informal division of fishing space and 2) fishing grounds formally managed as a common property regime. Ecuador's cockle fishery has experienced harvesting pressures in the last 10 years (Mora \& Moreno, 2009; Mora, Moreno, \& Jurado, 2011), further exacerbated by habitat destruction due to decades of mangrove deforestation associated with shrimp aquaculture (MacKenzie, 2001; OcampoThomason, 2006). Shifts from top-down to bottom-up approaches in coastal management during the late 1990s signaled an unprecedented recognition of ancestral rights for coastal inhabitants, resulting in new property arrangements called custodias. The custodias represent agreements between Ecuador's Ministry of Environment and local associations, which aim to protect mangrove forests and provide a framework for community-based management of mangrove-associated artisanal fisheries. To date, there are 51 custodias distributed throughout the five coastal provinces (Mestanza, 2014). The arrangement is similar to co-management institutions in other parts of Latin America (Gallardo Fernandez \& Friman, 2011; Gelcich, Edwards-Jones, Kaiser, \& Castilla, 2006; Pinto da Silva, 2004; Van Holt, 2012).

The local association in Isla Costa Rica was one of the first in the southern province of El Oro to receive a custodia. Their management plan specifies closure periods, rules of use and access to a particular set of specially managed cockle beds within the custodia boundaries (Bravo \& Altamirano, 2006) similar to Ostrom's design principles of a common property regime (Beitl, 2011; Ostrom, 1990). Other cockle beds within the custodia are harvested daily, operating on a first-come, first served basis. These open-access areas within the custodia and beyond its boundaries are informally divided among individuals based on personal preferences, habitual use, and mutual respect (Beitl, 2014). The following sections will explore the complementary nature of these two systems at a local scale illustrating the ways in which common pool resource theory and human behavioral ecology are well-positioned to contribute to a spatially explicit theory of the commons with critical implications for fisheries management. 


\section{Spatializing Commons Theory}

\subsection{Theoretical Framework}

Common pool resource (CPR) theory has typically classified social-ecological systems into a typology of property regimes including public, private, common property, and open-access (Feeny et al., 1990; Ostrom, Burger, Field, Norgaard, \& Policansky, 1999). Giordano's (2003) spatially-explicit theory of the commons is based on a typology of resource characteristics along the lines of fugitive, migratory, and open-access, which reflects variations in geography to better understand the interaction between the spatial domains of the resource base and its users. Moss (2014) points out that spatial concepts like space, place, territory, and scale have been treated more as a fixed means of categorization in the commons literature rather than an object of analysis in and of itself. Moss further highlights the essentializing tendencies of the institutional literature on the commons, which has narrowly conceived of space as a static biophysical realm, thereby failing to appreciate the dynamic human-environment interactions, cultural-political dimensions, various forms of agency, and alternative geographies that shape the production, use, and regulation of the commons (Moss, 2014). Combining ethnographic research on the fishery commons with human behavioral ecology has the potential to address some of these deficiencies in commons theory since spatial and temporal patterns in harvesting behavior represent a dynamic human-environment interface.

From a human behavioral ecology perspective, cockles are sessile and predictable like other shellfish, making them susceptible to overexploitation (Thomas, 2007a). This is especially true in open-access situations where the domains of multiple users overlap because of poorly defined property rights (Giordano, 2003) and low communication levels among resource users (Janssen \& Ostrom, 2008). On the other hand, from the perspective of CPR theory, it is because of the sedentary nature of shellfish that resource users may find it easier to devise institutions and invest in a management strategy, as in the case of Maine's soft shell clam fishery (Hanna, 1998) and other benthic fisheries (Basurto et al., 2012). The relatively stationary characteristics of lobsters may have also contributed to the widely documented emergence of a governance system in Maine's lobster fishery characterized by an informal system of territoriality among "lobster gangs," and a more formal system of co-management (Acheson, 1988; Acheson, 2003; Acheson \& Gardner, 2004; Wilson et al., 2007). Wilson and colleagues have argued that such forms of collective action have emerged out of the self-interested behavior of competing fishers (Wilson et al., 2013; Wilson et al., 2007; Wilson, Acheson, \& Johnson, 2013).

Different OFT models have allowed researchers to test predictions about what kinds of strategies allow foragers to optimize their harvesting efficiency. For example, the prey choice model predicts which species should be targeted for optimal caloric profitability (Thomas, 2007a). The patch choice model tests whether resource users will abandon patches when the returns fall below their expected return rates, or mean profitability for all patches in the environment (Charnov, 1976; Chimello de Oliveira \& Begossi, 2011; Sosis, 2002). Sosis (2002) has adapted the patch-choice model to explore daily variation in fishing effort among Ifaluk fishers for bluefin tuna. His results show that fishers switch to alternative patches (fishing grounds) when catch rates drop below the per capita mean of the average catch rate for all patches. He argues these daily 
variations in catch rates are one possible explanation for why fishers do not consistently exploit the most profitable patches all of the time, a nuance which is often obscured by the aggregated averages in other patch choice studies. Chimello de Oliveira and Begossi (2011) used a similar approach to study patch choices among small-scale shrimp fishers in Brazil and also found that fishers moved on when the return rate of the previous trip dropped below average.

Patch-choice models allow for a spatially explicit analysis of the dynamic movement of resource users over a patchy environment. This application of the patchchoice model adds to a large body of research that uses ecological concepts to gain better understanding of human-environment interactions that promote (or work against) conservation with implications for resource management like niche partitioning (Nunes, Hartz, \& Silvano, 2011) or territoriality (Acheson, 1987; Begossi, 1995; Begossi, 2001; Begossi, 2006).

\subsection{Hypotheses}

Optimal foraging models contain several assumptions, but the two assumptions most relevant to this research are: 1) that fishers have perfect information about the "quality" of fishing grounds and 2) the availability of resources within those fishing grounds will decline with accelerating gains, similar to the subtractability problem in the commons literature. While fishers do not have perfect information about the environment, it is relatively safe to assume that fishers in Isla Costa Rica have a specialized understanding about their preferred fishing grounds, which developed out of habitual use (Beitl, 2014). Based on these two assumptions, this study tests the following hypotheses:

H1: Cockle collectors switch fishing grounds when their catch rate drops below the average gross return rate for all the fishing grounds in the environment.

$\mathrm{H} 2$ : Patterns of fisher mobility are further influenced by the cultural and institutional context.

Given the limitations of optimal foraging models, I do not rely on the sole use of the patch choice model to explain the observed patterns in fishing effort. I also draw upon 21 months of ethnographic research on Ecuador's cockle fishery to aid my interpretation of model results and substantiate the implications for management.

\section{Material and Methods}

\subsection{Description of Study Area}

The Archipelago Jambelí in Ecuador's southern province of El Oro is a landscape mosaic comprised of mangrove forests, shrimp farms, custodias, and urban areas. The main study area for this research is the village of Isla Costa Rica, a rural parish with around 300 inhabitants located about $8.6 \mathrm{~km}$ from Puerto Hualtaco and the city of Huaquillas on the Peruvian border. The climate is dry and tropical with an average temperature of $25.4^{\circ} \mathrm{C}$. The annual precipitation is about $300 \mathrm{~mm}$ with the highest amounts of rainfall from December to May. 
Similar to the other rural fishing villages throughout the Archipelago Jambelí, the residents of Isla Costa Rica rely primarily on mangrove-associated artisanal fisheries for a living. Residents harvest mangrove resources for subsistence and commercial markets, including mangrove cockles and crabs, shrimp, beach clams, and a variety of finfish species. Some households grow subsistence crops in home gardens, predominantly watermelon, aloe vera, lemongrass, and passion fruit. Women and girls engage primarily in domestic tasks while men and boys fish and collect cockles. There is one primary school and since the year 2010, additional teachers from urban centers spend four days of the week on the island to offer secondary school-level education, meaning that migration to urban areas has no longer been a requirement in the past few years for those residents who wish to continue their education. Almost half of the island's 70 households have one or more individuals who collect cockles on a full time basis, defined as 2-4 hours per day, 5-6 days per week. The other half engage primarily in other fishing activities and parttime cockle collecting.

As described briefly in the introduction, the cockle fishery in Isla Costa Rica is characterized as a mixed management system because of the custodia. The boundaries of the custodia do not encompass all the fishing grounds utilized by cockle collectors in Isla Costa Rica, and not all the fishing grounds within the custodia are managed as a common property regime with special rules regulating use and access (see Figure 1). Smaller circles represent fishing grounds that are harvested daily and generally function as openaccess (OA) in the sense that neither territorial defense nor the exclusion of outsiders is enforced. Larger circles represent the areas managed as a common property resource regime (CPR). The rules governing the CPR areas were designed and mutually agreed upon by members of the association. The rules include 10 harvest days after 30 -day closure periods, restrictions on shell size permissible for market $(45 \mathrm{~mm}$ in length, in line with central government regulations), and a rotating guard duty by each member to to prevent entry by outsiders. The rules of access have changed over time as the association experimented with different management strategies that best supported social, ecological, and economic needs of the community. For example, areas that were once harvested after 3-6 month closure periods are now only closed for 30 days. But the obligations of membership have remained consistent as each member of the association has been required to serve guard duty. Those who fail to fulfill this obligation are sanctioned.

Zones represent a geographical clustering of fishing grounds based on physical features such as waterways and cultural features like the names of areas designated by members of the community (see Figure 1). For example, Zone 1 is locally referred to as "San Gregorio." Zone 2 is "aquí atrás." Zone 3 is "Sector Corazones." Locals refer to the fishing grounds managed as common property as "las areas," which lie somewhere between the boundaries of Zones 1 and 2. The cultural features of these zones were further elaborated in a previous study of the fishing effort in Isla Costa Rica, which revealed an informal division of fishing space based on personal preferences, habitual use, and mutual respect among individual cockle collectors from the community and beyond (see Beitl, 2014, for a more in-depth ethnographic description of the fishery). Grouping fishing grounds into these four zones was necessary in this study to further discern patterns of mobility and explore how fishers navigate over fishing space under formal and informal governance systems in Isla Costa Rica. 


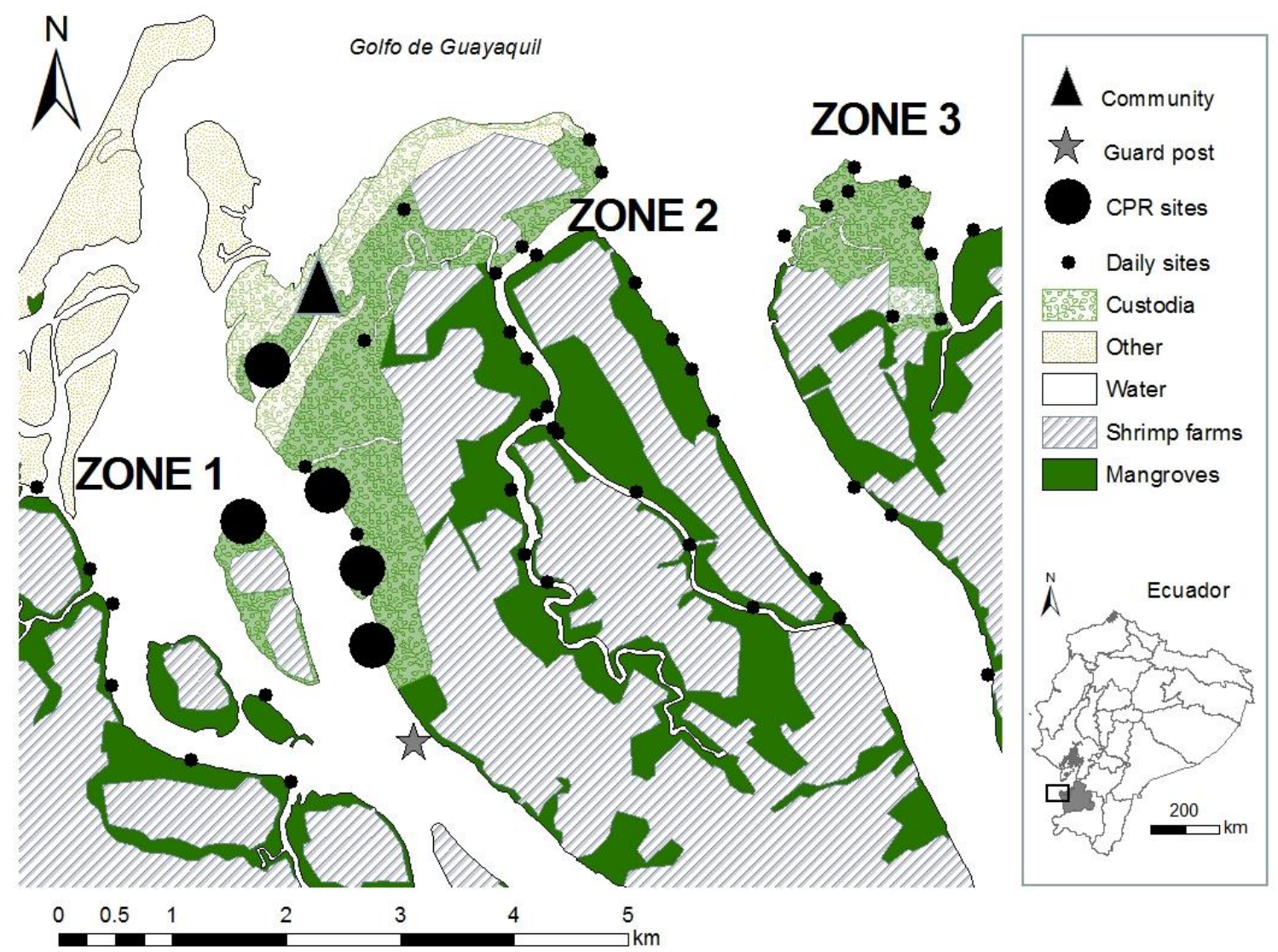

Figure 1. Map of the study area Isla Costa Rica. The map illustrates: 1) the area in custodia; 2) "daily sites," or the locations of fishing grounds harvested daily; 3 ) fishing grounds harvested monthly and managed as a common property regime (larger circles); and 4) the informal division of fishing space into three zones. Map compiled by author. Data Sources: Asociación Isla Costa Rica (2010); PMRC-CLIRSEN (2006); Bravo \& Altamirano (2006).

\subsection{Methods of Data Collection}

This research is part of a larger ethnographic study of Ecuador's cockle fishery based on 21 months of multi-sited fieldwork from 2006 to 2010. The observational data presented here was collected over a period of 115 continuous days from March 8 to June 30,2010 . There were 27 individuals who agreed to report their daily catch, the number of hours fished, the name of fishing grounds, and their alternative activity if they did not go cockle collecting (Asociación de Mariscadores Pescadores Artesanales y Afines "Costa Rica", 2010). The sample of 27 included 20 members from the Asociación Costa Rica and one member from the community's other association. The remaining six participants were their sons under the age of 18 and therefore not eligible for association membership. This sample represents almost half of the community's estimated 70 part-time and fulltime cockle collectors. One field assistant collected the information from those 27 participants on a daily basis. The field assistant also documented additional fishers to calculate the total fishing effort for the day, as well as the number of outsiders and general locations where they were observed. 


\subsection{Methods of data analysis}

CPUE in the cockle fishery is defined by Ecuador's National Fisheries Research Institute as the total number of shells per unit of effort where each individual fisher represents one unit of effort, and total effort refers to the total number of cockle collectors on a given day (Mora et al., 2011). CPUE is a common fishery-dependent statistic used in fisheries science to estimate the stock of a given species (NOAA, n.d.). This is similar to the concept of return rate in the behavioral ecology literature that usually divides the total catch by the total time invested. A simple expression of this concept can be represented by the following equation:

$\mathrm{R}=\mathrm{CPUE} / \mathrm{T}$ where $\mathrm{R}$ is the return rate; CPUE is the total number of shells harvested by an individual on a trip; and $\mathrm{T}$ is the number of hours that individual spent fishing.

This formula was used to calculate the return rate for each fishing trip observation in the dataset $(n=1,544)$ and a threshold average of 26.33 shells harvested per hour for all the fishing grounds in Isla Costa Rica. ${ }^{1}$

To further prepare the data for analysis, each observation was coded as a CPR day when the specially managed areas were open for harvest and an $O A$ day when they were closed. I used Analysis of Variance (ANOVA) to compare differences between the two governance systems (OA vs. CPR). Then to test the first hypothesis (whether fishers move on or stay put when return rates of a previous fishing trip fall below the mean), a set of variables were coded as dichotomous dummy variables. For example, if the return rate for an individual dropped below the average return rate for all areas, the observation was coded 1 for "yes" and 0 for "no." The same coding technique was used to classify whether the return rate was above or below the mean by fishing ground, by zone, and by individual fisher, and whether the fisher switched fishing grounds or zones in response to a drop in return rates below the average. I employed a cross-tabulation and chi-squared analysis to calculate likelihood ratios and test the relationship between return rates and the decision to move on. The Pearson's chi-square is appropriate to test the likelihood that two categorical variables occur together (with four possible outcomes). A Fisher's exact test was used to test for statistical significance. All statistical analyses were conducted using SPSS Version 22. I further drew upon the ethnographic research on the cockle fishery and Isla Costa Rica to interpret the results.

\section{Results}

Out of 3,103 observations over a period of 115 days, 1,544 fishing trips were recorded for the 27 participants who reported information about their daily livelihood activities from March 8 to June 30. No one fished on Good Friday (April 2) or during the local holiday, Fiesta Patronal (June 12), or any of the 16 Sundays in this dataset. The $\mathrm{CPR}$ areas were open for the 10-day group harvest on three occasions during the field season: 1) March 12-23; 2) April 24-May 5; and 3) June 7-18. Fishing effort increased during the second and third CPR harvest periods as many association members chose to take advantage of the higher return rates associated with the CPR areas (Figures 2 and 3). The average daily catch rates were highly variable and there appeared to be a slight

\footnotetext{
${ }^{1}$ Observations with no data (i.e. 16 Sundays, 2 holidays, and several observations in which certain individuals engaged in alternate activities) were dropped from the analyses.
} 
increase in effort and decline in catch rates during April and June compared to March, a trend that is more pronounced during the CPR periods.

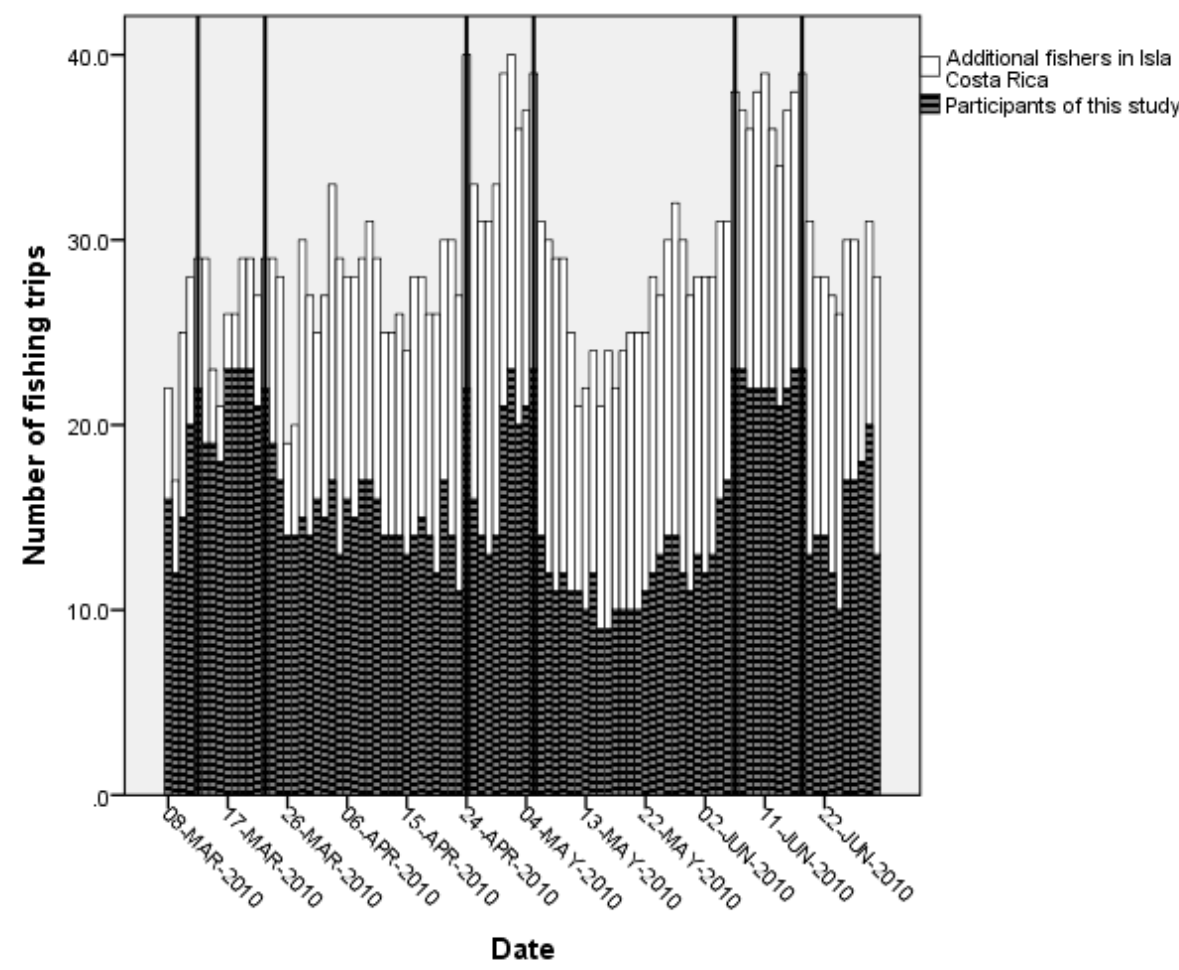

Figure 2. Fishing effort by people in Isla Costa Rica over time (March 8 - June 30) indicated by the sum of fishing trips by the 27 participants in this research plus additional fishers from the community. Reference lines group together the 10-day open and 30-day closed periods of the CPR areas.

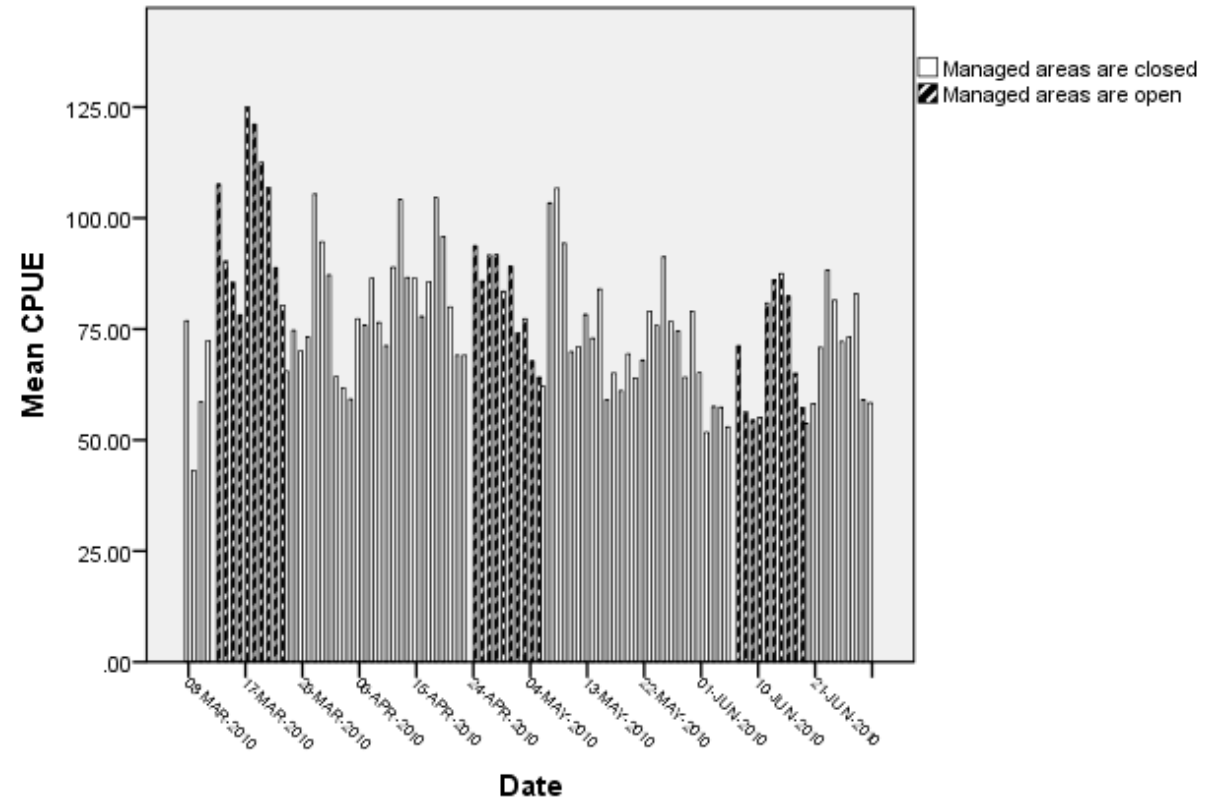

Figure 3. Average daily CPUE in Isla Costa Rica (March 8-June 30, 2010) self-reported by 27 participants. 
There are significant differences in catch rates between areas that operate as open access and those managed by the local association as a common property regime. As indicated in Table 1, the average CPUE in the CPR areas is 10 shells higher than the OA areas and the percentage of trips in which an individual's catch dropped below the average return rate is slightly lower (51\% in CPR vs. 57\% in OA areas). The same trend holds true for when return rates fall below the average return rates by individual. In other words, OA areas are associated with a higher likelihood that daily return rates drop below the average return rates by each fisher and the threshold average of 26.33 shells per hour for all fishing grounds in the community. The table also indicates that fishers move around much more within zones than across zones. Moreover, such mobility of fishers is higher in OA fishing grounds (73\%) compared with CPR grounds (38\%). Finally, fishers engaged less in alternative livelihood activities on the days that the CPR areas were open for harvest ( $24 \%$ of the observations compared with $49 \%$ of the observations on OA days). 
Table 1. Descriptive statistics comparing differences between management regime types, open-access (OA) and common property regime (CPR) $(n=1,544)$.

\begin{tabular}{lcccc}
\hline Variable & OA & CPR & $\begin{array}{c}F- \\
\text { statistic }\end{array}$ & $p$-value* \\
\hline & & & & \\
Catch-per-unit-effort (CPUE) & 74 & 84 & 35.490 & $0.000^{*}$ \\
Average number of hours spent fishing & 2.95 & 3.02 & 12.055 & $0.001^{*}$ \\
Number of shells per hour & 25.5 & 27.8 & 20.643 & $0.000^{*}$ \\
& & & & \\
Whether return rates drop below means & & & & \\
Returns < mean return for all fishing grounds (26.3) (\%) & 57 & 51 & 5.157 & $0.025^{*}$ \\
Returns < mean return by fishing ground (\%) & 55 & 58 & 1.266 & 0.261 \\
Returns < mean return by zone (\%) & 55 & 58 & 1.620 & 0.203 \\
Returns < mean return by fisher (\%) & 65 & 54 & 17.329 & $0.000^{*}$ \\
& & & & \\
Whether fishers decide to move on or stay put & & & & \\
Switch fishing ground (\%) & 73 & 38 & 217.184 & $0.000^{*}$ \\
Switch zone (\%) & 44 & 12 & 197.890 & $0.000^{*}$ \\
Likelihood of engaging in an alternate activity (\%) & 49 & 24 & 162.427 & $0.000^{*}$ \\
\hline
\end{tabular}

Figures 4 and 5 illustrate the dynamic movement of fishers over time by summarizing the frequency by which they stay put or move on to a new fishing ground under the conditions that their return rate of the previous fishing trip dropped below the threshold average of 26.33 shells harvested per hour. Figure 4 suggests that alternating among fishing grounds is quite common, regardless of return rates of a previous day. However, the likelihood of moving on to a new fishing ground increases with statistical significance when return rates of a previous fishing trip dropped below the average. Figure 5 indicates that alternating among zones is much less common than alternating among sites within a zone. On the other hand, the same pattern holds true that the likelihood of zone-switching also increases when return rates of a previous day drop below the mean. 


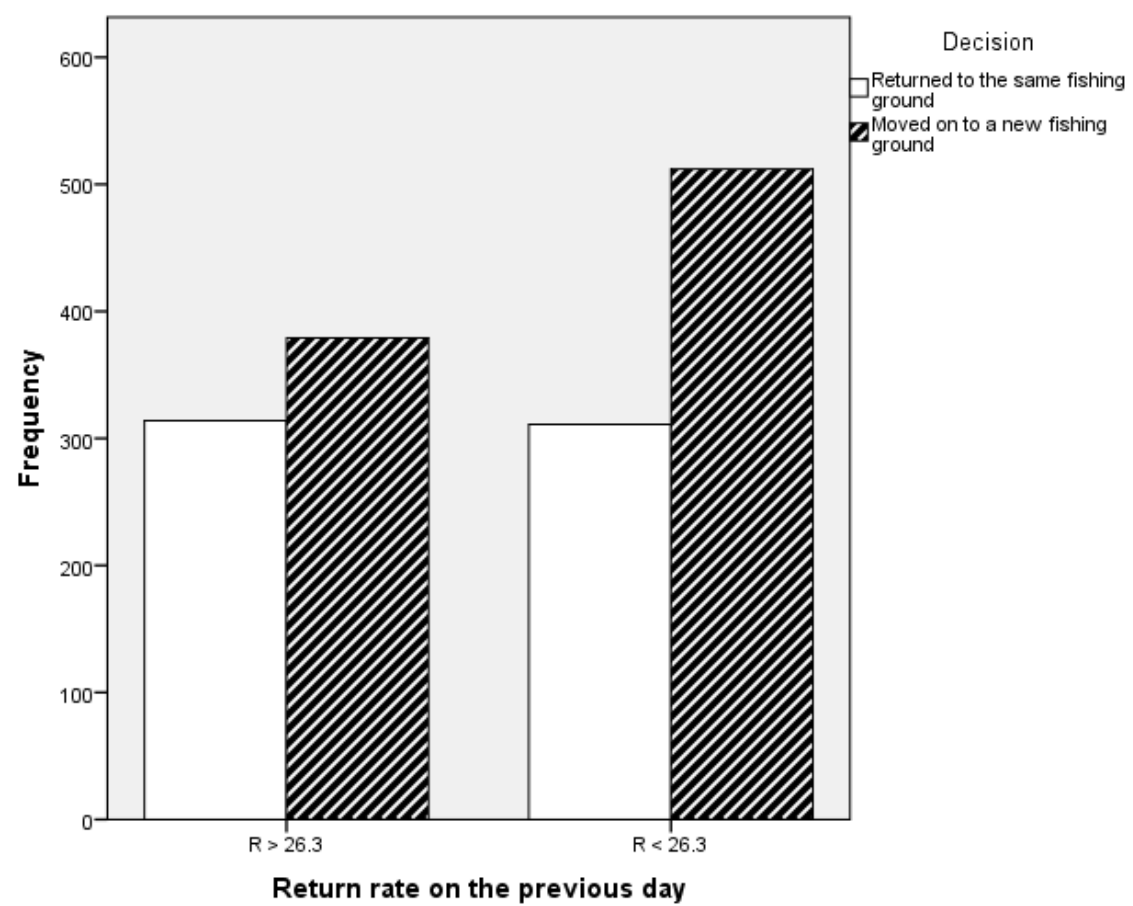

Figure 4. Frequency that fishers moved on to a new fishing ground after return rates fell below the average during the previous fishing trip. $X^{2}=8.784 ; p$-value $=0.002 ; \mathrm{n}=1,516$.

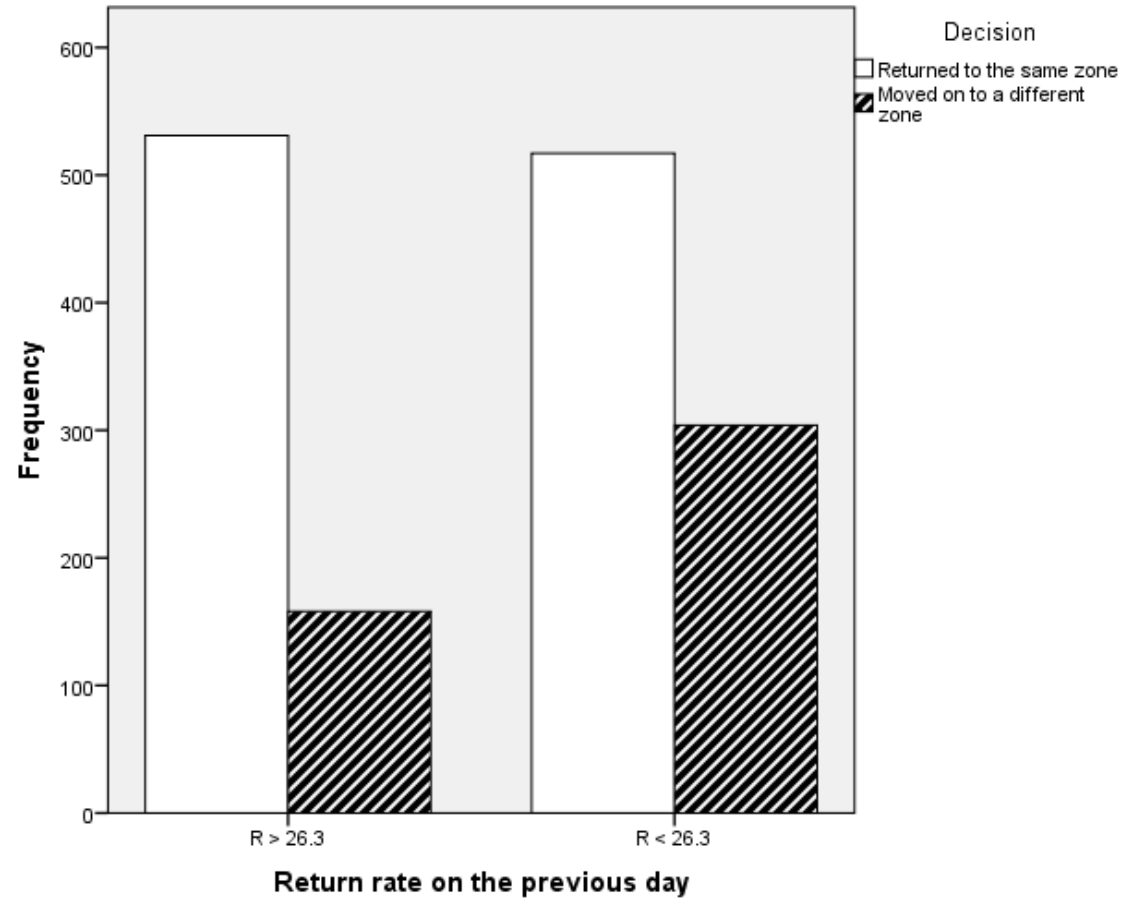

Figure 5. Frequency that fishers moved on to a new zone after return rates fell below the average during the previous fishing trip. $X^{2}=35.054 ; p$-value $=0.000 ; \mathrm{n}=1,510$. 


\section{Discussion}

\subsection{Catch rates, decision-making, and fisher mobility}

Individual decision-making among cockle collectors in Isla Costa Rica is partially explained by optimal foraging theory's patch choice model (Chimello de Oliveira \& Begossi, 2011; Sosis, 2002; Thomas, 2007b). Even though alternating fishing grounds in Isla Costa Rica is common regardless of the return rates of a previous fishing trip, the likelihood of moving on appears to increase as a response to diminishing returns. From the perspective of human behavioral ecology, this finding suggests that fishers employ optimal strategies to seek the most productive fishing grounds and then move on when those areas are no longer profitable. These patterns of alternation among fishing grounds in response to previous-day catch rates are also similar to the individual search strategy described by Wilson and colleagues (2007) as one of the initial stages of fisher behavior prior to the formation of groups in their computational model simulating the emergence of governance in the Maine lobster fishery.

On the other hand, fishers may not always be cognizant of when catch rates fall below an expected return rate. Changes at small temporal and spatial scales may be too marginal for cockle collectors to consciously perceive in ways that inform their daily decisions. As such, cockle fishers do not always switch fishing grounds when catch rates fall below the average and sometimes switch fishing grounds regardless of the catch rate on a previous day. This phenomenon is most likely accounted for by several other cultural factors not systematically studied here, such as risk avoidance or travel costs, which may be prioritized over any desire to maximize catch rates. Many studies have documented non-ecological factors influencing spatial and temporal dimensions of fishing behavior, such as perceptions about safety and fuel costs (Daw, 2008; Teh et al., 2012; Van Oostenbrugge, Densen, \& Machiels, 2001), access controls (Basurto, 2005; Basurto et al., 2012), engagement in some level of occupational pluralism (Daw et al., 2012; Griffith \& Valdés Pizzini, 2002; McCay, 1978), or other non-economic factors like personal obligations or illness (Guest, 2003). Moreover, individuals are differentiated by unique harvesting strategies. For example, some fishers alternate frequently within and across zones while others have clear preferences and habitually harvest particular zones even if they are less productive (Beitl, 2014). A spatially-explicit theory of the commons considers such spatial and temporal dimensions in the dynamic social production of fishing space, which is discussed in more detail in the following section.

\subsection{Dynamic cultural production of the commons and patterns of mobility}

Some geographers emphasize the importance of understanding the ways in which the commons are socially constructed to embody certain human values (McDermott, 2014; Shaw, 2014). These value systems, in turn, serve as an informal institution encompassing unspoken rules, norms, or a moral code. The mangrove-fishery commons in Ecuador has been characterized by an ethos of open access similar to what Moritz and others (2013) have described about West African pastoral systems. Cockle fishers in Ecuador generally believe that all fishers should have the right to harvest fish from mangroves as long as they do not destroy them. In other words, no one should be excluded from coastal wetlands except for shrimp farmers who have bulldozed the mangroves away for the construction of their shrimp ponds over the last several decades. 
Despite the first-come, first-served nature of access in the cockle fishery, fishers in Isla Costa Rica habitually harvest their preferred fishing grounds but do not actively defend them (Beitl, 2014). This de facto system of preferences allows fishers the freedom of movement based on their individualized knowledge, expertise, and judgment, as opposed to the more structured collective choice agreements about the rules of rotation and harvest that define the CPR managed areas. The informal system operates based on a combination of aggregated self-interested preferences (Wilson et al., 2007) within a culture of mutual respect and avoidance (McGoodwin, 1994; Moritz et al., 2013; Nunes et al., 2011). While the informal division of fishing space can influence humanenvironment dynamics, it can best be described as a loosely governed commons characterized by flexibility and high levels of mobility among fishing grounds, especially in comparison to the explicit rule structure governing access to the CPR areas.

Assuming that fishers generally conform to the system of preferences that shape the informal division of fishing space in open-access areas, the strategy of alternating among fishing grounds permits cockle bed recovery after an exploitation event potentially mitigating against depletion. Fishers are able to draw upon their ecological and biological knowledge about cockles to allow fishing grounds sufficient time to rest before the next harvest period. This local ecological understanding has informed the harvest schedule for the set of fishing grounds in Isla Costa Rica managed as a CPR. These areas serve as a reserve area for cockle spawning and growth during its closure periods. Because of the strict set of rules governing harvest periods, the fishing grounds managed as common property are associated with larger shell sizes and higher catch rates (see also Beitl, 2011). Thus, from a behavioral ecology perspective, fishers accept the short-term costs of vacating the more profitable sites (CPR areas) for less productive fishing grounds (OA areas) to allow for resource renewal (Ruttan, 1998; Sosis, 2002; Thomas, 2007b). This acceptance of short term costs has allowed conditions that permit local investment and collective action in the areas managed as a CPR. Regardless of whether cockle collectors are cognizant of when daily catch rates fall below an expected return rate, the mobility of individuals under formal and informal institutional arrangements may be a critical factor sustaining common pool resources in Isla Costa Rica.

In the last several decades, this spirit of open access has been threatened by multiple challenges such as increasing competition, displacement by shrimp farming, and pollution. In many ways, custodias have helped coastal people reclaim their ancestral fishing spaces after their livelihoods were undermined by export-oriented growth and development of shrimp aquaculture. The custodias have granted new forms of agency that have restructured the interactions between artisanal fishers and their resource space through community-based resource management. They embody the ways in which ideologies of universal access have shifted to an acceptance of several group proprietorships. The changing valuation of public goods and ancestral rights has led to the emergence of a new rule structure embodied by the common property regime, which operates alongside the informal system of individual preferences. Both systems of governance are highly complementary and allow for a certain "economics of flexibility" (McCay, 1978; McCay, 2002). The CPR areas within custodias promote social, ecological, and economic benefits for fishers who have access privileges. They provide an ecological reserve for shellfish management and further provide incentives for 
individuals with access rights to invest in conservation. In turn, the fishing grounds outside the formally managed CPR permit an economic safety net for fishers throughout the country when alternative livelihood options are limited due to seasonal patterns in other fisheries or the country's larger economic conditions. The mixed property arrangements combining CPR and OA suggest interesting possibilities for the management of shellfish fisheries at similar scales.

\subsection{Epiphenomenal resource management and the issue of scale}

In the fisheries literature, optimizing strategies have been associated with overexploitation (Gordon, 1954) and a tragedy of the commons (Hardin, 1968). Some researchers have likened the moving on pattern to "roving banditry" or a fishing down trend that eventually leads to extirpation (Berkes et al., 2006), especially when management solutions are not aligned with ecological realities at appropriate scales (Johnson et al., 2012; Wilson, 2006). On the other hand, optimizing strategies requiring rotation among multiple fishing grounds in Isla Costa Rica may permit a form of unintended resource management or self-organization at the system level, which ensures relatively reliable returns for individuals and potentially mitigates against a tragedy in open-access areas not managed as common property. Open access systems that operate in a similar fashion, in which resource users can enjoy the freedom of movement, do not always result in a tragedy of the commons even on larger spatial and temporal scales, as documented in West African pastoral systems (Moritz, Hamilton, Chen, \& Scholte, 2014; Moritz, Scholte, Hamilton, \& Kari, 2013). While Figure 3 indicates catch rates are higher during March compared to April and June, the scope of this study does not capture seasonality in fishing effort or fishery productivity, which has not been systematically studied in Ecuador's cockle fishery. Both biologists and fishers in Ecuador believe that cockles spawn in January and February, possibly resulting in higher catch rates around that time.

Epiphenomenal resource management is often possible in small scale societies or low population densities even if conservation is not intentional (Begossi, 1995, 2006; Lu, 2001; Smith \& Wishnie, 2000). However, as many geographers have pointed out, the problem of the commons largely depends on the spatial, temporal, and technological scale at which it is assessed (Campbell, 2007; Giordano, 2003). At this micro-scale of cockle fishing in Isla Costa Rica, fishing space is shared among few users with a level of fishing effort that is appropriate for the current market demands and available resource space. As such, the resource domain is spatially small enough for a fisher to apply his local ecological knowledge about cockle biology while also drawing upon the cultural knowledge he has about the behavior of other fishers who share the same fishing space. In this way, one's "attachment to place" is not compromised, which lays a solid foundation and cultural conditions for collective action or some other form of informal resource management (Berkes et al., 2006). Many cockle fishers in Ecuador enjoy the freedom of open access and perceive relatively reliable return rates, especially in comparison with other mangrove fisheries associated with higher levels of investment in fishing gear and uncertainty. For some Ecuadorians, cockle collecting is a primary livelihood profession which they practice on a year-round, day-to-day basis. Others fall back on cockle fishing as a safety net when economic times are difficult or in congruence with seasonal patterns in other fisheries. 
On the other hand, the open access nature of the cockle fishery in Ecuador may allow cumulative effects of declining catch rates due to uncontrolled fishing effort on larger spatial and temporal scales. Many cockle fishers are concerned that the fishing effort increased during the late 1990s at the end of the shrimp boom that attracted so many migrants to the coast during the 1980s. A disease in cultured shrimp forced the abandonment of many shrimp farms leaving many skilled and unskilled laborers in coastal communities no choice but to enter one of Ecuador's open-access artisanal fisheries. The cockle fishery was the most accessible because of the negligible amounts of investment required (rubber boots and gloves are optional). Thus while the technological scale of this fishery is of minimal impact at the local level, the commons problem is more pronounced on a larger temporal scale. Even though there is a general perception of reliable return rates on a day-to-day basis, many fishers increasingly find it challenging to let their preferred fishing grounds rest two to four weeks after a harvest according to their local ecological knowledge and understanding about resource renewal. Many fishers are also concerned about new competition and the loss of fishing space due to mangrove destruction by shrimp farms or enclosure by other custodias, pointing to the ways in which the problem of the commons is also shaped by alternative cultural, political, and economic geographies (Beitl, 2012; Martinez-Alier, 2001; Moss, 2014).

\section{Conclusions}

Decades of research on the commons and customary marine tenure institutions have generated much debate about whether humans are self-interested actors maximizing their exploitation of resources as predicted by optimal foraging theories, or whether conservation outcomes can emerge within the context of certain institutional arrangements and property regimes. This case study has illustrated that optimizing strategies requiring rotation among fishing grounds may be one factor contributing to epiphenomenal resource management. Resource user mobility in response to previousday catch rates and the rules of cultural institutions may be key factors mitigating against a tragedy of the commons in open-access areas not managed as a common property regime. However, the cohesion of such a flexible social structure may break down on larger spatial and temporal scales as "scaling up" the management of the commons has long been considered a challenge (Arias Schreiber \& Halliday, 2013; Berkes, 2005; Ostrom et al., 1999).

On the other hand, the commons are socially constructed to embody human values and this case of the cockle fishery in Ecuador illustrates the highly dynamic nature of space, place, and territory in the commons. Custodias represent a fundamental shift in values that once embraced an ethos of open access. Now the tenet of proprietorship embodies a new way of valuing mangrove forests and ancestral community rights, with implications for empowerment among disenfranchised fishers. In turn, these political processes have influenced the nature of human-environment interactions in the cockle fishery by transforming the individual choices of a free-for-all into the collective choice agreements of the CPR. While the emergent social structures that define rules of use are qualitatively different, these two governance systems are complementary in the case of Isla Costa Rica, and neither system should replace the other. The fishers' alternation between formal and informal systems of governance has allowed for adaptive feedback between social, economic, and ecological systems. This direct attention to social- 
ecological feedback may provide interesting insights for the management of other fishery commons at similar scales. However more systematic research is needed on how individual and collective choice decisions affect the dynamics of fishing effort allocation at broader spatial and temporal scales.

\section{References}

Abernethy, K. E., Allison, E. H., Molloy, P. P., \& Côté, I. M. (2007). Why do fishers fish where they fish? Using the ideal free distribution to understand the behaviour of artisanal reef fishers. Canadian Journal of Fisheries \& Aquatic Sciences, 64(11), 1595-1604.

Acheson, J. (1987). The Lobster Fiefs Revisited: Economic and Ecological Effects of Territoriality in the Maine Lobster Fishery. In B. J. McCay \& J. M. Acheson (Eds.), The Question of the Commons: The Culture and Ecology of Communal Resources (pp. 37-65). Tucson: University of Arizona Press.

Acheson, J. (2011). Coming Up Empty: Management Failure of the New England Ground Fishery. MAST, 10(1), 57-86.

Acheson, J. M. (1988). The lobster gangs of Maine: Upne.

Acheson, J. M. (2003). Capturing the commons: devising institutions to manage the Maine lobster industry. Hanover, NH: University Press of New England.

Acheson, J. M., \& Gardner, R. J. (2004). Strategies, Conflict, and the Emergence of Territoriality: The Case of the Maine Lobster Industry. American Anthropologist, 106(2), 296-307. doi: 10.1525/aa.2004.106.2.296

Agrawal, A. (2001). Common Property Institutions and Sustainable Governance of Resources. World Development, 29(10), 1649-1672.

Arias Schreiber, M., \& Halliday, A. (2013). Uncommon among the Commons? Disentangling the Sustainability of the Peruvian Anchovy Fishery. Ecology and Society, 18(2). doi: 10.5751/ES-05319-180212

Asociación de Mariscadores Pescadores Artesanales y Afines "Costa Rica". (2010). Proyecto de Monitoreo Comunitario del Recurso Concha Prieta. Coordinado por Christine Beitl, Adolfo Cruz y Sonia Cruz, Isla Costa Rica, enero - junio de 2010.

Aswani, S. (1998). Patterns of marine harvest effort in southwestern New Georgia, Solomon Islands: resource management or optimal foraging? Ocean and Coastal Management, 40(2-3), 207-235.

Aswani, S. (1998). The Use of Optimal Foraging Theory to Assess the Fishing Strategies of Pacific Island Artisanal Fishers: A Methodological Review. Traditional Marine Resource Management Knowledge Inform. Bull., 9, 21-26.

Basurto, X. (2005). How Locally Designed Access and Use Controls Can Prevent the Tragedy of the Commons in a Mexican Small-Scale Fishing Community. Society \& Natural Resources, 18(7), 643-659.

Basurto, X., Cinti, A., Bourillón, L., Rojo, M., Torre, J., \& Weaver, A. (2012). The Emergence of Access Controls in Small-Scale Fishing Commons: A Comparative Analysis of Individual Licenses and Common Property-Rights in Two Mexican Communities. Human Ecology: An Interdisciplinary Journal, 40(4), 597-609. doi: 10.1007/s10745-012-9508-1

Begossi, A. (1995). Fishing Spots and Sea Tenure: Incipient Forms of Local Management in Atlantic forest Coastal Communities Human Ecology, 23(3), 387-406. 
Begossi, A. (2001). Mapping spots: Fishing Areas or Territories Among Islanders of the Atlantic Forest (Brazil) Reg Environmental Change, 2, 1-12.

Begossi, A. (2006). Temporal Stability in Fishing Spots: Conservation and CoManagement in Brazilian Artisanal Coastal Fisheries. Ecology and Society, 11(1), 25.

Beitl, C. M. (2011). Cockles in Custody: The Role of Common Property Arrangements in the Ecological Sustainability of Mangrove Fisheries on the Ecuadorian Coast. International Journal of the Commons, 5(2), 485-512. Online: http://tinyurl.com/c482gv482ey.

Beitl, C. M. (2012). Shifting Policies, Access, and the Tragedy of Enclosures in Ecuadorian Mangrove Fisheries: Towards a Political Ecology of the Commons. Journal of Political Ecology, 19, 94-113. Online: http://jpe.library.arizona.edu/Volume119/Volume_119.html.

Beitl, C. M. (2014). Navigating Over Space and Time: Fishing Effort Allocation and the Development of Customary Norms in an Open-Access Mangrove Estuary in Ecuador. Human Ecology, 42(3), 395-411. doi: 10.1007/s10745-014-9655-7

Béné, C., \& Tewfik, A. (2001). Fishing Effort Allocation and Fishermen's Decision Making Process in a Multi-Species Small-Scale Fishery: Analysis of the Conch and Lobster Fishery in Turks and Caicos Islands. Human Ecology, 29(2), 157186.

Berkes, F. (2001). Managing Small-Scale Fisheries: Alternative Directions and Methods. Ottawa: International Development Research Centre.

Berkes, F. (2005). Commons Theory for Marine Resource Management in a Complex World. Senri Ethnological Studies, 67, 13-31.

Berkes, F., Hughes, T. P., Steneck, R. S., Wilson, J. A., Bellwood, D. R., Crona, B., . . . Worm, B. (2006). Globalization, Roving Bandits, and Marine Resources. Science, 311(5767), 1557-1558. doi: 10.1126/science.1122804

Bravo, M., \& Altamirano, M. (2006). Actualización del Plan de Manejo del Manglar Concesionado a la Asociación de Pescadores Artesanales, Mariscadores y Afines Costa Rica: Archipiélago de Jambelí Programa de Manejo de Recursos Costeros, Procedimiento CCI No. PMRC-035-2005 (pp. 1-61). Guayaquil, Ecuador.

Bromley, D. W., \& Feeny, D. (1992). Making the Commons Work: Theory, Practice, and Policy. San Francisco: Institute for Contemporary Studies.

Campbell, L. M. (2007). Local Conservation Practice and Global Discourse: A Political Ecology of Sea Turtle Conservation. Annals of the Association of American Geographers, 97(2), 313-334. doi: 10.1111/j.1467-8306.2007.00538.x

Charnov, E. L. (1976). Optimal Foraging: The Marginal Value Theorem. Theoretical Population Biology, 9, 129-136.

Chimello de Oliveira, L., \& Begossi, A. (2011). Last Trip Return Rate Influence Patch Choice Decisions of Small-Scale Shrimp Trawlers: Optimal Foraging in São Francisco, Coastal Brazil. Human Ecology, 39(3), 323-332. doi: 10.1007/s10745011-9397-8

Colding, J., \& Folke, C. (2001). Social taboos:" Invisible" systems of local resource management and biodiversity conservation. Ecological Applications, 11(2), 584600 . 
Daw, T. M. (2008). Spatial distribution of effort by artisanal fishers: Exploring economic factors affecting the lobster fisheries of the Corn Islands, Nicaragua. Fisheries Research, 90(1-3), 17-25. doi: http://dx.doi.org/10.1016/j.fishres.2007.09.027

Daw, T. M., Cinner, J. E., McClanahan, T. R., Brown, K., Stead, S. M., Graham, N. A. J., \& Maina, J. (2012). To Fish or ot to Fish: Factors at Multiple Scales Affecting Artisanal Fishers' Readiness to Exit a Declining Fishery. PLoS ONE, 7(2), 1-10. doi: 10.1371/journal.pone.0031460

Dyer, C. L., \& McGoodwin, J. R. (Eds.). (1994). Folk Management in the World's Fisheries: Lessons for Modern Fisheries Management. Niwot, CO: University Press ofo Colorado.

Feeny, D., Berkes, F., McCay, B. J., \& Acheson, J. M. (1990). Tragedy of the Commons: Twenty-two years later. Human Ecology, 18(2), 1-19.

Gallardo Fernandez, G., \& Friman, E. (2011). New Marine Commons along the Chilean Coast - The Management Areas (MAs) of Peñuelas and Chigualoco. International Journal of the Commons, 5(2), 433-458.

Gelcich, S., Edwards-Jones, G., Kaiser, M. J., \& Castilla, J. C. (2006). Co-management Policy Can Reduce Resilience in Traditionally Managed Marine Ecosystems. Ecosystems, 9(6), 951-966. doi: 10.1007/s10021-005-0007-8

Giordano, M. (2003). The Geography of the Commons: The Role of Scale and Space. Annals of the Association of American Geographers, 93(2), 365-375. doi: 10.1111/1467-8306.9302007

Gordon, H. S. (1954). The Economic Theory of a Common-Property Resource: The Fishery. The Journal of Political Economy, 62(2), 124-142.

Griffith, D. C., \& Valdés Pizzini, M. (2002). Fishers at work, workers at sea: a Puerto Rican journey through labor and refuge. Philadelphia: Temple University Press.

Guest, G. (2003). Fishing Behavior and Decision-Making in an Ecuadorian Community: A Scaled Approach. Human Ecology, 31(4), 611-644.

Hanna, S. (1998). Managing for Human and Ecological Context in the Maine Soft Shell Clam Fishery. In F. Berkes, C. Folke \& J. Colding (Eds.), Linking Social and Ecological Systems: Management Practices and Social Mechanisms for Building Resilience (pp. 190-211). Cambridge ; New York: Cambridge University Press.

Hanna, S., Folke, C., \& Mäler, K.-G. (1996). Rights to nature: ecological, economic, cultural, and political principles of institutions for the environment. Washington, D.C.: Island Press.

Hanna, S., \& Munasinghe, M. (Eds.). (1995). Property Rights and the Environment: Social and Ecological Issues. Washington, D.C., U.S.A.: Beijer International Institute of Ecological Economics and the World Bank.

Hardin, G. (1968). Tragedy of the Commons. Science, 162, 1243-1248.

Heinen, J. T. (1995). Applications of human behavioural ecology to sustainable wildlife conservation and use programmes in developing nations. Oryx, 29(3), 178-186.

Heinen, J. T. (1996). Human Behavior, Incentives, and Protected Area Management. Conservation Biology, 10(2), 681-684.

Heinen, J. T., \& Low, R. S. (1992). Human Behavioral Ecology and Environmental Conservation. Environmental Conservation, 19(2), 105-116.

Hilborn, R. (2007). Managing fisheries is managing people: what has been learned? Fish and Fisheries, 8(4), 285-296. doi: 10.1111/j.1467-2979.2007.00263_2.x 
Janssen, M. A., \& Ostrom, E. (2008). TURFS in the lab: Institutional Innovation in RealTime Dynamic Spatial Commons. Rationality and Society, 20(4), 371-397. doi: 10.1177/1043463108096786

Johannes, R. E. (1978). Traditional Marine Conservation Methods in Oceania and their Demise. Annual Review of Ecology and Systematics, 9, 349-364.

Johannes, R. E. (2002). Did Indigenous Conservation Ethics Exist? SPC Traditional Marine Resource Management and Knowledge Information Bulletin, 14(October 2002), 3-7.

Johnson, T. R., Wilson, J. A., Cleaver, C., \& Vadas, R. L. (2012). Social-Ecological Scale Mismatches and the Collapse of the Sea Urchin Fishery in Maine, USA. Ecology and Society, 17(2). doi: 10.5751/ES-04767-170215

Kelly, R. L. (1995). The Foraging Spectrum: Diversity in Hunter-Gatherer Lifeways. Washington: Smithsonian Institution Press.

Lu, F. E. (2001). The Common Property Pegime of the Huaorani Indians of Ecuador: Implications and Challenges to Conservation. Human Ecology, 29(4), 425-447.

MacKenzie, C. (2001). The Fisheries for Mangrove Cockles, Anadara spp., from Mexico to Peru, With Descriptions of Their Habitats and Biology, the Fishermen's Lives, and the Effects of Shrimp Farming Marine Fisheries Review, 63(1), 1-39.

Martinez-Alier, J. (2001). Ecological Conflicts and Valuation: Mangroves versus Shrimps in the Late 1990s. Environment and Planning C-Government and Policy, 19(5), 713-728.

McCay, B. (1978). Systems ecology, people ecology, and the anthropology of fishing communities. Human Ecology, 6(4), 397-422.

McCay, B. J. (2002). Emergence of Institutions for the Commons: Contexts, Situations, and Events. In E. Ostrom, T. Dietz, N. Dolsak, P. C. Stern, S. Stonich, E. U. Weber \& National Research Council (U.S.). Committee on the Human Dimensions of Global Change. (Eds.), The Drama of the Commons (pp. 361-402). Washington, DC: National Academy Press.

McCay, B. J., \& Acheson, J. M. (1987). The Question of the Commons: The Culture and Ecology of Communal Resources. Tucson: University of Arizona Press.

McDermott, M. (2014). Introduction. Community Development Journal, 49(suppl 1), i1i11. doi: 10.1093/cdj/bsu010

McGoodwin, J. R. (1994). "Nowadays, Nobody Has Any Respect": The Demise of Folk Management in a Rural Mexican Fishery. In C. L. Dyer \& J. R. McGoodwin (Eds.), Folk Management in the World's Fisheries: Lessons for Modern Fisheries Management (pp. 43-54). Niwot, CO: University Press ofo Colorado.

Mestanza, J. C. (2014, 12 de agosto 2014). 51 concesiones en cinco provincias apuestan a la defensa del manglar. August 12, 2014. El Comercio. Retrieved from http://www.elcomercio.com/actualidad/concesiones-provincias-ecuador-defensamanglar.html. Accessed 10/30/2014

Mora, E., \& Moreno, J. (2009). La Pesqueria Artesanal del Recurso Concha (Andara tuberculosa y A. similis) en la Costa Ecuatoriana durante el 2004. Boletín Cientifico y Técnico, 20(1), 1-16.

Mora, E., Moreno, J., \& Jurado, V. (2011). Un Análisis de la Pesquería del Recurso Concha en Ecuador Durante el 2010 Boletin Científico Técnico, 21(2), 1-13. 
Moritz, M., Hamilton, I. M., Chen, Y.-J., \& Scholte, P. (2014). Mobile pastoralists in the Logone Floodplain distribute themselves in an Ideal Free Distribution. Current Anthropology, 55(1), 000.

Moritz, M., Scholte, P., Hamilton, I., \& Kari, S. (2013). Open Access, Open Systems: Pastoral Management of Common Pool Resources in the Chad Basin. Human Ecology, 41, 351-365.

Moss, T. (2014). Spatiality of the Commons. International Journal of the Commons, 8(2), 457-471.

NOAA. (n.d.). NOAA Fisheries Office of Protected Resources: Glossary. Retrieved 2/19/12, 2012

Nunes, D. M., Hartz, S. M., \& Silvano, R. A. M. (2011). Fishing Strategies and Niche Partitioning Among Coastal Fishers in Southern Brazil. Human Ecology, 39(4), 535-545. doi: 10.1007/s10745-011-9411-1

Ocampo-Thomason, P. (2006). Mangroves, People and Cockles: Impacts of the ShrimpFarming Industry on Mangrove Communities in Esmeraldas Province, Ecuador. In C. T. Hoanh, T. P. Tuong, J. W. Gowing \& B. Hardy (Eds.), Environment and Livelihoods in Tropical Coastal Zones: Managing Agriculture-FisheryAquaculture Conflicts (pp. 140-153). Oxon, UK: CAB International.

Ostrom, E. (1990). Governing the Commons: Evolution of Institutions for Collective Action. Cambridge: Cambridge University Press.

Ostrom, E., Burger, J., Field, C. B., Norgaard, R. B., \& Policansky, D. (1999). Revisiting the Commons: Local Lessons, Global Challenges. Science, 284, 278-282.

Pinto da Silva, P. (2004). From common property to co-management: lessons from Brazil's first maritime extractive reserve. Marine Policy, 28(5), 419-428. doi: 10.1016/j.marpol.2003.10.017

Pollnac, R., \& Johnson, J. (2005). Folk Management and Conservation of Marine Resources: Towards a Theoretical and Methodological Assessment. In N. Kishigami, J. M. Savelle \& K. M. Hakubutsukan. (Eds.), Indigenous Use and Management of Marine Resources (pp. 33-50). Suita, Osaka: National Museum of Ethnology.

Ruttan, L. (1998). Closing the Commons: Cooperation for Gain or Restraint? Human Ecology, 26(1), 43-66.

Salas, S., \& Gaertner, D. (2004). The behavioural dynamics of fishers: management implications. Fish and Fisheries, 5(2), 153-167. doi: 10.1111/j.14672979.2004.00146.x

Schlager, E., \& Ostrom, E. (1999). Property Rights Regimes and Coastal Fisheries: An Empirical Analysis. In M. D. McGinnis (Ed.), Polycentric Governance and Development : Readings from the Workshop in Political Theory and Policy Analysis (pp. 87-113). Ann Arbor: University of Michigan Press.

Shaw, M. (2014). Learning from The Wealth of the Commons: a review essay. Community Development Journal, 49(suppl 1), i12-i20. doi: 10.1093/cdj/bsu012

Smith, E. A., \& Wishnie, M. (2000). Conservation and Subsistence in Small-Scale Societies. Annual Review of Anthropology, 29(1), 493.

Sosis, R. (2002). Patch Choice Decisions among Ifaluk Fishers. American Anthropologist, 104(2), 583-598. doi: 10.1525/aa.2002.104.2.583 
Teh, L., Teh, L., \& Meitner, M. (2012). Preferred Resource Spaces and Fisher Flexibility: Implications for Spatial Management of Small-Scale Fisheries. Human Ecology, 40(2), 213-226.

Thomas, F. (2007a). The Behavioral Ecology of Shellfish Gathering in Western Kiribati, Micronesia 1: Prey Choice. Human Ecology, 35(2), 179-194.

Thomas, F. (2007b). The Behavioral Ecology of Shellfish Gathering in Western Kiribati, Micronesia. 2: Patch Choice, Patch Sampling, and Risk. Human Ecology: An Interdisciplinary Journal, 35(5), 515-526. doi: 10.1007/s10745-007-9119-4

Thomas, F., R. . (2001). Remodeling Marine Tenure on the Atolls: A Case Study from Western Kiribati, Micronesia. Human Ecology, V29(4), 399-423.

Tucker, B. (2007). Applying Behavioral Ecology and Behavioral Economics to Conservation and Development Planning: An Example from the Mikea Forest, Madagascar. Human Nature, 18(3), 190-208.

Tucker, B., \& Rende Taylor, L. (2007). The Human Behavioral Ecology of Contemporary World Issues. Human Nature, 18(3), 181-189.

Van Holt, T. (2012). Landscape Influences on Fisher Success: Adaptation Strategies in Closed and Open Access Fisheries in Southern Chile. Ecology and Society, 17(1). doi: 10.5751/ES-04608-170128

Van Oostenbrugge, J. A. E., Densen, W. L. T. v., \& Machiels, M. A. M. (2001). Risk aversion in allocating fishing effort in a highly uncertain coastal fishery for pelagic fish, Moluccas, Indonesia. Canadian Journal of Fisheries and Aquatic Sciences, 58(8), 1683-1691.

Wilson, J. (2006). Matching Social and Ecological Systems in Complex Ocean Fisheries. Ecology and Society, 11(1), 9 [online] URL: http://www.ecologyandsociety.org/vol11/iss11/art19/.

Wilson, J., Hill, J., Kersula, M., Wilson, C. L., Whitsel, L., Yan, L., . . Wilson, C. J. (2013). Costly information and the evolution of self-organization in a small, complex economy. Journal of Economic Behavior \& Organization, 90, Supplement(0), S76-S93. doi: http://dx.doi.org/10.1016/j.jebo.2012.12.019

Wilson, J., Yan, L., \& Wilson, C. (2007). The precursors of governance in the Maine lobster fishery. Proceedings of the National Academy of Sciences, 104(39), 15212-15217. doi: 10.1073/pnas.0702241104

Wilson, J. A., Acheson, J. M., \& Johnson, T. R. (2013). The cost of useful knowledge and collective action in three fisheries. Ecological Economics, 96(0), 165-172. doi: http://dx.doi.org/10.1016/j.ecolecon.2013.09.012 